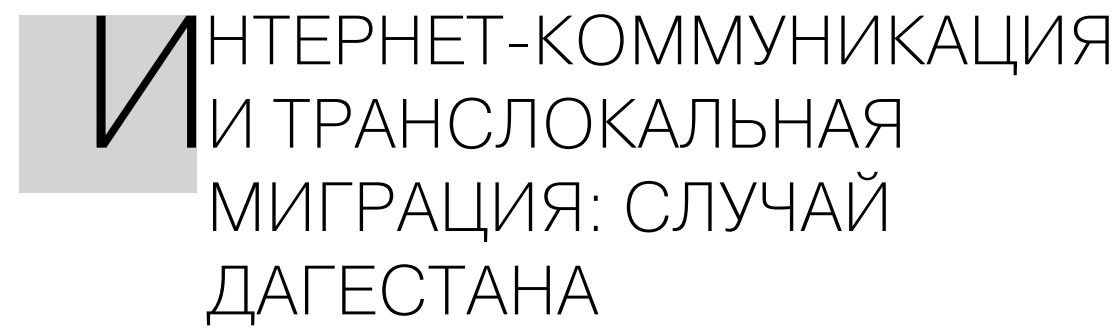

\title{
Екатерина Капустина
}

Екатерина Капустина, Музей антропологии и этнографии им. Петра Великого (Кунсткамера) РАН; Европейский университет в Санкт-Петербурге. Адрес для переписки: МАЭ РАН, Университетская наб., 3, Санкт-Петербург, 199034, Pоссия.parlel@mail.ru.

Статья написана при поддержке Российского научного фонда, грант № 1418-02149-П «Транснациональные и транслокальные аспекты миграции в современной России», проект осуществлен в Европейском университете в Санкт-Петербурге (2017-2018 г2.).

В статье рассматривается специфика использования интернет-коммуникации (в первую очередь социальных медиа) в транслокальных сельских сообществах Дагестана в условиях внутрироссийской миграции в индустриальные города за пределы республики. Транслокальность стала реальностью для многих дагестанских сообществ, когда в постсоветский период значительная часть сельского населения была вовлечена в трудовую миграцию и уезжала в крупные города и индустриальные центры России. Несмотря на то, что мигранты перемещаются внутри одной страны, огромные расстояния, долгосрочный режим миграции и различные социокультурные и экономические условия жизни в отправляющем и принимающем обществах стали вызовом для сохранения единства в сельском джамаате и актуальности сельской идентичности, которая очень значима даже для тех, кто уже десятки лет работает вдали от Дагестана. В статье показаны варианты использования социальных медиа трансмигрантами, членами их семей и односельчанами, а также определены основные функции мобильных социальных сетей. Кроме того, в тексте рассматривается, как различные социальные медиа служат способом коммуникации между мигрантами и оставшимися на родине, а также площадкой для решения важных социальных задач мигрантских семей и транслокального сельского сообщества. Сельские чаты консолидируют сообщество и формулируют идею единства земляков, актуализирующуюся в миграции, фактически обеспечивая полноценную транслокальность сообществу. Социальные медиа также становятся определенным силовым и экономическим ресурсом в миграции, они могут предложить новые варианты отправления религиозных ритуалов. В то же время чаты сельских жителей становятся способом демонстрации индивидуальной и семейной репутации и источником как позитивного, так и негативного социального капитала. В этой связи они могут быть опасны для мигрантов, в первую очередь - женщин, поскольку провоцируют разные формы насилия по отношению к ним.

Ключевые слова: транслокальное общество; миграция; цифровая антропология; социальные медиа; социальные мигрантские сети; социальный капитал 
Миграционные исследования как междисциплинарное научное направление являются отражением развития современных социальных наук. Все актуальные и острые темы и подходы так или иначе апробируются в работах, посвященных миграционной проблематике, пропускаются через миграционную призму или помещаются в миграционный контекст. Поскольку в настоящее время в социальных науках большое внимание уделяется интернет-технологиям, а цифровой мир, его агенты и потребители стали значимыми участниками различных социальных процессов, то неудивительно, что направление digital studies стало одним из самых актуальных в исследованиях миграций и мобильности. В частности, эти исследования часто фокусируются на поведении мигрантов в виртуальной реальности, а также на использовании ими интернет-коммуникаций и, шире, цифровых технологий.

Статья посвящена одному из частных случаев влияния цифрового мира на мигрантские практики. Речь пойдет о внутрироссийской, преимущественно трудовой, миграции из сельских районов Республики Дагестан в крупные и средние города России. Я предлагаю рассмотреть один из аспектов социальной реальности дагестанского мигранта - роль интернет-коммуникаций, прежде всего социальных медиа (социальные сети, мессенджеры), в современном опыте миграции. Под социальными медиа я буду понимать различные массовые коммуникационные интернет-платформы.

Прежде чем определить основные цели и задачи исследования и перейти к главной теме статьи, необходимо кратко охарактеризовать специфику современной дагестанской внутрироссийской трудовой миграции и дать обзор концепций транснационализма и транслокальности, применение которых продуктивно для исследования данного случая.

\section{ТЕОРЕТИЧЕСКАЯ РАМКА ИССЛЕДОВАНИЯ}

Теоретическая позиция, которая, на мой взгляд, может быть применима при анализе дагестанской миграции из сел республики в российские центры притяжения трудовых мигрантов, связана с концепцией транснационализма, одного из актуальных теоретических направлений антропологии миграции в последние десятилетия. Согласно этому подходу, миграция может называться транснациональной, если участвующие в ней мигранты развивают и поддерживают множественные формы отношений, пересекающие границы, и строят свои публичные идентичности при взаимодействии с более чем одним национальным государством (Glick Schiller, Basch, and Blanc-Szanton 1992:ix). Исследователи таким образом отказываются от понимания миграции как однонаправленного процесса, обращая внимание на тот факт, что уехав, люди так или иначе сохраняют свое присутствие на прежнем месте жительства. Нина Глик Шиллер с коллегами, одни из первых упоминавшие о транснационализме в контексте антропологии миграции, назвали таких мигрантов трансмигрантами (iх).

В рамках этого подхода формулируется понятие транснационального сообщества как сообщества, в котором локальные отношения распространяются через границы (Goldring 1999; Levitt 2001; Smith and Guarnizo 1998). Новое понятие 
отчасти пересекается с привычным и прочно обосновавшимся в социальных науках и общественном дискурсе понятием «диаспора». Для одних исследователей эти термины фактически тождественны (Tölölyan 1996), другие, рассматривая их, склонны выделять принципиальные различия. Так, по мнению Томаса Файста, диаспоральное сообщество и те, кто остались дома, нередко живут в разных социальных мирах, тогда как транснационализм, оперирующий конкретными практиками мигрантов, обращает внимание скорее на функционирование сетей и различные трансграничные взаимодействия (Faist 2010).

Описанная «первопроходцами» концепции Файстом, Глик Шиллер и другими ситуация транснациональной миграции подразумевает перемещение мигранта за пределы своей страны и его дальнейшее существование в особом транснациональном социальном пространстве, включающем два или более национальных государства. Однако схожие процессы происходят и в ситуациях миграции людей внутри одного государства.

Как правило, в этом случае исследователи используют термин транслокальность, который рассматривается некоторыми авторами как частный случай транснациональной миграции без пересечения национальных границ. Действительно, в некоторых регионах мира внутренняя миграция по масштабам, последствиям и сложности сопоставима и даже порой превосходит международную; внутрироссийская миграция - очевидно, такой случай. Однако существует и другой взгляд на понятие транслокальности: интерес исследователей может быть смещен в сторону от проблематики взаимодействия национальных государств и трансмигрантов (тема стала одной из центральных, в частности, в работах Глик-Шиллер и ее соавторов). В этом случае внимание уделяется взаимодействию локальностей, впрочем, одновременно расширяется круг проблем, которые могут быть освещены через это понятие, а термин «транслокальность» используется и для анализа кейсов международной миграции (Greiner and Sakdapolrak 2013; Peleikis 2003).

В этой интерпретации транслокальность становится зонтичным термином для определения мобильности и различных форм пространственных связанностей (Greiner 2010). При таком подходе внимание сосредоточено на разнонаправленных и перекрывающих друг друга сетях, которые способствуют циркуляции людей, ресурсов, практик и идей, находящихся в разных локальностях. Центральной идеей для определения транслокальности стала идея мобильности, движения и потоков - например, денежных переводов и товаров, а также символических потоков - стилей, идей, символов (Greiner and Sakdapolrak 2013).

В этой статье термин «транслокальность» использован для обозначения отсутствия государственных границ и переноса внимания с национального государства на уровень мобильности и связанных с ней социальных процессов в локальных сообществах. Обращение к этому понятию, на мой взгляд, оправданно и продуктивно при изучении современных мигрантских практик дагестанцев, выезжающих в трудовую миграцию в крупные российские города. 


\section{СПЕЦИФИКА ДАГЕСТАНСКОЙ МИГРАЦИИ: ПОЧЕМУ ЕЕ МОЖНО НАЗВАТЬ ТРАНСЛОКАЛЬНОЙ?}

Республика Дагестан представляет собой классический пример российского региона-донора: в миграции, по разным оценкам, находятся от одной десятой до четверти населения республики, почти в каждой семье есть миграционный опыт. По своим причинам миграция из Дагестана довольно типична: как и во многих других регионах, людей побуждают к отъезду безработица и низкий уровень жизни, однако в ней есть и своя специфика, выражающаяся в сохранении постоянных и достаточно глубоких контактов с родственниками, а главное - с другими сельчанами, членами сельского сообщества (джамаата) - как оставшимися на малой родине, так и находящимися в миграции. Джамаат для дагестанской реальности многозначный термин, в настоящее время применяющийся и по отношению к собранию выборных представителей села, и к сельскому сообществу в целом. Кроме того, джамаат может восприниматься и как мусульманская община прихожан одной мечети. На деле вторая и третья социальные структуры зачастую тождественны друг другу, поскольку абсолютное большинство жителей дагестанских селений считают себя мусульманами (хотя далеко не в каждом селе это большинство активно посещает мечеть).

Рассуждая о степени важности сельского сообщества для социальной структуры современного Дагестана, важно учитывать специфику дагестанской системы родства. Дагестанский тухум - это не обширные многопоколенные экзогамные родовые сообщества, характерные для других регионов Северного Кавказа, а семейно-родственное патрилинейное образование в несколько поколений, причем нередко преимущественно эндогамное. В настоящее время тухум - это фактически круг достаточно близкой родни по отцовской линии. В таких условиях вместо фамильной солидарности как важного условия консолидации на Северном Кавказе здесь на первый план выходит солидарность сельская, подкрепленная сельской эндогамией.

История политической независимости многих селений также сыграла свою роль: значительная часть горных сел до эпохи Кавказской войны (1817-1859для территории Дагестана) входила в вольные общества и фактически обладала политическим суверенитетом, память о котором актуальна в местных политических и общественных дебатах и сейчас. Следует принимать во внимание и такие факторы, как лингвистическая дробность и неоднозначность этнической идентичности, которая также актуализирует локальную сельскую идентичность.

Тем не менее, масштабные миграции как внутри республики, так и за ее пределы приводят к тому, что классической стала ситуация, когда в горном селении проживает во много раз меньше семей, чем за его пределами. У выходцев из села есть несколько направлений отъезда: помимо трудовой миграции за пределы Дагестана сельчане переселяются в «свои» села на равнине. Плановое и - реже стихийное переселение, организованное советскими властями с середины XX века, образовало систему, когда почти каждое горное и предгорное селение в республике имеет селение-дублера на равнинных землях, чаще всего ранее выде- 
ленных для нужд отгонного скотоводства ${ }^{1}$. Достаточно массовым в последние десятилетия стало и переселение горцев (и сельчан в целом) в города республики и ее столицу - Махачкалу. Это привело к тому, что в селе-метрополии проживает в несколько раз меньше людей, чем в местах переселения - равнинных селах, дагестанских городах и за пределами Республики Дагестан. Если в рамках республики сельский ресурс по-прежнему достаточно актуален, то миграция на более дальние расстояния является вызовом его мощности и вообще существованию. В таких условиях сельские сообщества, локализованные и цельные еще несколько десятилетий назад, в настоящее время переживают существенные социально-пространственные трансформации, сказывающиеся, помимо прочего, на сельской идентичности, ее актуальности и доступности, в особенности для тех, кто оказался в миграции.

Высокая мобильность дагестанского сельского населения, и прежде всего массовая миграция за пределы республики - как правило, за тысячи километров от дома, - при сохранении тесных связей между уехавшими и оставшимися позволяет говорить о транслокальности современного сельского сообщества Дагестана. Дагестанское транслокальное сообщество может включать в себя жителей горного селения, переселенческого населенного пункта на равнине, городов Дагестана и тех городов в миграции за пределами республики, которые актуальны для того или иного села. Его транслокальность формируется и поддерживается через интенсивные перемещения между отправляющим и принимающим сообществами, экономические инвестиции и в место миграции, и в отправляющее сообщество, проведение части значимых ритуалов (свадебные, похоронно-поминальные и некоторые другие) в одном месте (а части - в другом) и прочие транслокальные практики дагестанских трансмигрантов ${ }^{2}$. Способствует сохранению транслокальности и невозможность полностью вписаться в жизнь принимающего сообщества, связанная не только с культурными и религиозными отличиями дагестанцев от основной части жителей российских городов, но и с кавказофобией и дискриминационными практиками по отношению к мигрантам с Северного Кавказа в России.

Взаимодействие между отправляющим обществом и мигрантом нередко определяется существованием эффективных социальных сетей, которые могут формироваться под влиянием разных факторов, но применительно к дагестанской миграции часто именно сельская (в большей степени, чем этническая, например) идентичность становится базой для их формирования.

Внимание к своему сельскому сообществу демонстрировали и в целом неуспешные мигранты, у которых процесс адаптации к принимающему сообществу, его членам и правилам не удался, и относительно удачно вписавшиеся в жизнь в миграции люди. Разумеется, в каждом селе степень единства сообщества и взаимодействия жителей села и уехавших в миграцию земляков может быть различна, а декларация единства джамаата не всегда в полной мере соотносится с бытующими в селениях практиками. Однако мои наблюдения показывают, что нередко

\footnotetext{
1 Подробнее об этом см.: Карпов и Капустина (2011).

2 Подробнее об этом см.: Kapustina (2019).
} 
дагестанские трудовые мигранты, долгое время работающие в миграции, не только оказываются вовлечены в решение личных или семейных экономических и социальных задач в селе, но и принимают активное участие во множестве мероприятий, направленных на упрочение благосостояния селения в целом и на консолидацию сельского сообщества. В разговорах об отношении мигрантов к сельскому джамаату некоторые информанты прямо утверждали, что и уехавшие, и оставшиеся так или иначе составляют единый джамаат.

Важность локальных сообществ и их инициатив в Дагестане связана и со спецификой политической и экономической ситуации в республике. Экономический кризис, характерный для многих регионов РФ в постсоветский период, протекает в Дагестане особенно остро. Параллельно с ним существуют и другие проблемы: безработица; низкие доходы населения; упадок промышленности; нерешенность земельного вопроса, порождающая конфликты; политическая клановость; различные источники насилия в регионе; отсутствие безопасности личности и собственности; очень высокая коррупция. Неформальные сообщества, организующиеся вокруг общественных организаций на базе села, мечети или сельчан-активистов, фактически замещают структуры власти различного уровня и берутся за действительно масштабные проекты: прокладка дорог, строительство локальных ГЭС, реставрация и даже реконструкция исторических зданий и кварталов, строительство и ремонт мечетей, медресе, кладбищ, спортивных залов, школ и т. п. Общественные работы по благоустройству села не только помогают поддерживать село и членов сельского сообщества - в отсутствие сколько-нибудь ощутимой поддержки властей разных уровней они становятся стимулом к консолидации сельского сообщества, живущего в условиях транслокальности.

\section{АНТРОПОЛОГИЯ СОЦИАЛЬНЫХ МЕДИА}

В среде исследователей, занимающихся digital studies, идет дискуссия о различии между виртуальными и реальными сторонами социальных явлений (Dekker and Engbersen 2014 и др.). В рамках этих дебатов Дэниэл Миллер и Хизер Хорст предлагают в принципе уйти от противопоставления реального и виртуального миров, отмечая что стоит говорить о виртуальной социальности не как новой социальной форме, а как новом аспекте старых форм социальных отношений (Miller and Horst 2012:13). Таким образом снимается сама проблема разграничения межличностного взаимодействия в рамках сообщества и контактов посредством интернеттехнологий (Komito 2011).

Миграционные исследования виртуальности формулируют свои специфические вопросы. Среди популярных тем цифровой антропологии миграции - использование мигрантами различных интернет-технологий, социальных медиа, мобильных устройств как объектов, влияние медиа на процесс формирования сообщества, деятельность этнических активистов и др. (см., например: Horst 2006; Komito 2011; Madianou and Miller 2012; Miller 2011 и т. д.). Много внимания уделяется роли интернета в формировании мигрантского сообщества в принимающем обществе, актуализации этнической или расовой идентичности в условиях 
миграции (Cohen 1997; Ignacio 2005) - эти вопросы близки основным задачам данной статьи. На материале российской миграции эта тема поднимается в статье Рустамжона Уринбоева, который отмечает важную роль социальных медиа для формирования виртуального узбекского махалля (территориального сообщества в Узбекистане - квартала или селения) в принимающем обществе - Москве (Уринбоев 2020).

В контексте транснационализма внимание к социальным сетям, построенным на интернет-основе, весьма оправданно. Именно новые социальные сети значительно увеличивают возможности мигрантов поддерживать семейные и родственные контакты на большом расстоянии, создавать обширные личные сети, участвовать в национальных дебатах отправляющих обществ через транснациональные ассоциации (Komito 2011). Мигрантам и немигрантам, оставшимся дома, все легче поддерживать связи, несмотря на значительную географическую удаленность. Это дает исследователям повод говорить о «смерти расстояния» (Cairncross 1997) 3 . Таким образом, постоянная, длящаяся, а не дискретная связь тех, кто уехал в миграцию и тех, кто остался дома, позволяет с большим правом говорить о формировании единого транснационального социального пространства и дает иммигрантам чувствовать принадлежность не только к мигрантскому сообществу, но и к транснациональному социальному сообществу на основе отправляющей локальности (Asal 2012).

Данная работа является частью масштабного исследования феномена транслокальной миграции между селами Республики Дагестан и индустриальными центрами страны (см., например: Капустина 2017; Kapustina 2019). Основной целью, поставленной в статье, является изучение роли социальных медиа в функционировании транслокальных сельских сообществ Республики Дагестан.

Главными задачами статьи стали определение основных функций социальных медиа и, шире, интернет-коммуникаций для мигрантов и для отправляющего их сообщества; выявление специфики использования интернет-коммуникации применительно к различным мигрантским практикам. В частности, меня интересует, какие задачи трансмигранты решают посредством обращения к социальным медиа и другим интернет-коммуникациям, какова специфика, ограничения и даже опасности их применения. Ответы на эти вопросы, на мой взгляд, помогут дать более объемную картину устройства транслокального сельского сообщества в Дагестане, его границ и возможностей.

Следует отметить, что использование данных из сети Интернет для изучения тех или иных аспектов социального устройства дагестанского общества уже не редкость для социальных исследователей (в работах многих антропологов и социологов - см., например: Глянц 2018; Ярлыкапов 2014 и др.). Привлекались материалы из социальных медиа и при работе с мигрантскими сообществами в крупных городах России. Однако внимание непосредственно к роли социальных медиа в жизни трансмигранта на российском материале все еще ново и явно недостаточ-

${ }^{3}$ В среде исследователей есть мнение, что мобильные устройства и интернет, напротив, могут создавать новые препоны и сложности во взаимодействии мигрантов с отправляющим сообществом (Бредникова [в печати]). 
но (см., например, Бредникова [в печати]; Уринбоев 2020), поэтому постановка вопроса об обращении к этому аспекту мигрантской жизни в контексте изучения прежде всего дагестанского социума кажется мне актуальной.

В основу статьи легли мои полевые материалы. Это в первую очередь полевые записи наблюдений, проводимых в семьях трансмигрантов - как в местах миграции, так и в селениях, откуда мигранты выехали и где, как правило, остались члены их семей. Материалом послужили также полуструктурированные и биографические интервью, собранные автором в городах Западной Сибири (Сургуте, Нижневартовске, Пыть-Яхе, Новом Уренгое), в Москве и Подмосковье (Москва, Домодедово) и в различных регионах Республики Дагестан (Цунтинский, Кайтагский, Хасавюртовский, Дахадаевский районы). Основной материал, полученный в ходе этих наблюдений, касается нескольких транслокальных сообществ, построенных на базе принадлежности к одному селу, однако помимо этого использовался материал и по другим селениям указанных районов. Большая часть работы проходила в 2016-2018 годах в рамках коллективного исследовательского проекта «Транснациональные и транслокальные аспекты миграции в современной России», лонгитюдного исследования миграции в крупные города России из стран ближнего зарубежья и схожих по условиям российских регионов. В рамках этого проекта было проведено около 100 интервью с информантами обоих полов в возрасте от 20 до 65 лет. В качестве информантов выступили трудовые мигранты, члены их семей, односельчане, оставшиеся в отправляющем сообществе, и земляки в миграции. Помимо этого проводился анализ данных, полученных из просмотра содержания групп в социальных сетях Instagram, Facebook, «ВКонтакте», WhatsApp (семейных, сельских, городских), в которых состояли информанты, а также отдельных сельских сайтов.

Сама идея поразмышлять над ролью социальных сетей в жизни сельского сообщества родилась из наблюдений и упоминаний информантами в интервью темы виртуального взаимодействия. В настоящее время интернет и мобильная связь доступны практически всем населенным пунктам в республике (редкие исключение -малонаселенные высокогорные села). Без преувеличения можно сказать, что социальными медиа пользуется большинство активного населения Дагестана ${ }^{4}$. Поэтому я в ходе работы над темой транслокального сельского джамаата и степени его реальности в условиях миграции стала, помимо прочих, задавать вопросы о специфике коммуникации информантов в интернете с членами семьи, односельчанами, соседями, а также о том, как именно они используют социальные сети - чаты, группы и т. п. Когда это было возможно, я просила посмотреть групповые чаты собеседников или рассказать о них, сама просматривала некоторые открытые сельские группы в различных социальных медиа. Полученные данные и стали материалом, который я рассматриваю в этой статье. Статья не претендует на

4 Особенной популярностью в республике пользуется WhatsApp. Отсутствие у меня «Вацапа» (так произносят название этого мессенджера в Дагестане) крайне изумляло моих информантов. После неоднократных упреков с их стороны в непрактичности и несовременности одна из информанток практически в приказном порядке установила эту программу на мой телефон («Ведь неудобно же общаться без нее!»). 
роль масштабного исследования социальных медиа для темы миграции вообще или изучения их роли в дагестанском обществе в целом, а является скорее первым этапом работы, на котором определяется место интернет-коммуникаций и потенциал их именно в социальной жизни транслокального сообщества, сформированного в результате современного этапа миграции из Дагестана в крупные города России 5 .

\section{ТРАНСЛОКАЛЬНЫЙ ДАГЕСТАНСКИЙ ДЖАМААТ И МОБИЛЬНЫЕ СОЦИАЛЬНЫЕ СЕТИ}

В распоряжении дагестанских мигрантов и их земляков, оставшихся на родине, имеется множество видов и типов интернет-коммуникации. Это программы для преимущественно индивидуального общения - Skyре и телефонные приложения: WhatsApp, Viber, Telegram, а также так называемые социальные медиа: Facebook, «ВКонтакте», Instagram и «0дноклассники». Какие-то более популярны в Дагестане, какие-то менее, мода на социальные интернет-сети достаточно быстро меняется (на момент написания статьи наибольшей популярностью в регионе пользуются Instagram и WhatsApp, в прошлом большое значение для коммуникации имели «0дноклассники» и Skype). Одни социальные медиаплатформы чаще объединяют более локальные группы для личного общения, другие больше приспособлены для крупных виртуальных сообществ. При этом, по моим наблюдениям, в республике все же нет одного доминантного социального медиа, все они сосуществуют одновременно и совместно. Для наименования этой сочетаемости, которое и позволяет говорить о digital culture, Мадяноу и Миллер выбрали слово полимедия: большинство людей использует сочетание различных медиа как интегрированную среду обитания, в которой каждая социальная сеть находит свою нишу в сочетании с остальными (Madianou and Miller 2012:3).

\section{КОНСОЛИДАЦИЯ ЧЛЕНОВ СЕЛЬСКОГО СООБЩЕСТВА}

Одна из самых значимых и, безусловно, лежащих на поверхности функций социальных медиа для трансмигранта - формирование удобного механизма поддержания социальных связей с земляками в принимающем обществе и - в условиях географической удаленности - с оставшимися на малой родине. В работах о влиянии социальных медиа на транснациональную миграцию эта задача интернеткоммуникаций рассматривается как основная (Brekke 2008; Komito 2011; Plaza and Below 2014).

И мигранты, и не участвующие в миграции односельчане нередко состоят в группах, организованных по принципу принадлежности к тому или иному дагестанскому селу, или же объединяются в группы выходцев из селения, живущих в

5 Весной 2020 года, когда статья была уже принята в печать, все мы оказались в драматической ситуации, связанной с пандемией COVID-19. Сетевая активность и сельская мобилизация посредством социальных сетей в Дагестане как реакция на опасности пандемии была очень показательна и в целом не опровергает полученных в статье результатов. Надеюсь включить анализ произошедших событий в следующие работы на эту тему. 
том или ином месте миграции. Посредством интернет-технологий нередко фактически создается пространство постоянного общения членов сельского сообщества вне зависимости от местонахождения, в итоге осведомленность и вовлеченность мигрантов в сельские дела сопоставима с вовлеченностью в них тех, кто остался в селе.

В последние несколько лет особенной популярностью для этих целей пользуется именно мессенджер WhatsApp. Специфика этой сети в том, что здесь можно создавать групповые чаты. В них родственники и односельчане обмениваются не только сообщениями, но и фотографиями, видео, надиктовывают друг другу аудиосообщения, перезваниваются. Социальные сети выступают в качестве социального клея, объединяя мигрантов и немигрантов (Vertovec 2004). Например, информантка, живущая в миграции в Подмосковье уже несколько лет, со смехом рассказывала, что она в курсе всех сельских сплетен, практически в реальном времени видела видео со всех пропущенных ею свадеб, знает, у кого в селе родила корова и кто какие обновки привез из очередной поездки на оптовый рынок.

Моя двоюродная сестра сидит дома (в селе), ей сын звонит с армии и фотку присылает - мама, у тети Аминат дом что-ли сгорел? Она: ты что, с ума сошел? А оказывается, в это время дом горел, он уже там в России, где служил, узнал по WhatsApp. Она вышла из дома, все бегут, оказывается, дом горит, а я и не знала [о пожаре] (Полевые материалы автора (далее ПМА) 2018, Аминат ${ }^{6}, 50$ лет, Республика Дагестан, Цунтинский район).

Очень часто на базе WhatsApp организуются группы односельчан и даже районные группы (в некоторых районах региональная/районная идентичность актуальна в не меньшей степени, чем этническая). (ельские группы - важный ресурс для того, чтобы быть в курсе локальных новостей: о запланированных мероприятиях и чрезвычайных происшествиях в селе можно узнать даже не задавая вопросов в формате личного диалога, а просто пролистывая ленту новостей в соответствующей группе. Трансмигрантам интересно все: предстоящие праздники (светские и религиозные), объявления о политических событиях, новости о пожарах и стихийных бедствиях и т. п.: «Я когда в Питере учился, что больница в селе сгорела, через Instagram узнал» (ПМА 2018, Ибрагим, 27 лет, Республика Дагестан, Цунтинский район).

Интернет-телефония также является средством консолидации мигрантов и немигрантов, актуализации имеющихся в селении связей, в первую очередь родственных, соседских и дружеских. Показательна моя зарисовка из полевого дневника, описывающая квартиру мигрантов из Кайтагского района Дагестана, которые уже десять лет живут в Сургуте, но поддерживают активные связи с близкими родственниками, соседями и дурзьями, оставшимися в селении. В просторной кухне-гостиной центральное место отведено огромному дивану, напротив которого висит телевизор. Молодой глава семьи Магомед в разговоре подчеркнул, что

6 Здесь и далее все имена информантов и родовых объединений (тухумов) изменены. 
купил именно такую модель телевизора, поскольку она поддерживает программу Skype, необходимую ему для частого общения с родными в селе. Действительно, в те несколько дней, что я провела в этой семье, каждый вечер устраивались сеансы видеосвязи с Дагестаном: Магомед садился на диван и последовательно обзванивал близких родственников, находящихся в селении и в Махачкале, беседовал с ними о разных мелочах прошедшего дня, спрашивал сельские новости, пересказывая их затем другим родственникам. Таким образом, он не только потреблял, но и активно участвовал в распространении локальных новостей, находясь в миграции. Разговор по Skype с видеотрансляцией по огромному плазменному телевизору стал для этой семьи своеобразным «окном в село», занимавшим к тому же фактически центральное место в мигрантском доме.

Консолидирующая роль социальных медиа, организованных по принципу принадлежности к одному селу или району, типологически связывает их с другими интернет-продуктами, построенными на основе локальности, - сельскими сайтами. С появлением интернет-технологий в республике у многих сел и районов появились собственные сайты, при этом часто наряду с официальными страницами муниципальных образований в сети появлялись сайты, созданные частными лицами (или заказанные ими у специалистов) и посвященные родным селениям, их прошлому и настоящему. Некоторые села имели по несколько таких страниц. Часть сельских сайтов ограничивалась деятельностью непосредственно их создателей, наиболее успешные проекты на определенном этапе вовлекали в свою орбиту многих односельчан. Интересно, что часто успешные и развивающиеся сайты наполняли и вели активисты, которые уже не проживали в селе (а, например, уехали в столицу республики) или даже в стране. Сайты могли быть посвящены селению в целом или являлись организационной площадкой объединений односельчан, как, у Кубачинского общественного совета или общества «Согратль» (подробнее об одном из примеров см.: Капустина 2012). На базе таких сайтов иногда проводились акции, которые фактически имели цель объединить транслокальный джамаат. Так, на сайте села Кубачи была выдвинута инициатива по проведению всемирной переписи кубачинцев. На других сайтах проводили сборы средств, необходимых для помощи односельчанам или на определенные сельские нужды.

Тем не менее, по моему мнению, консолидация вокруг сельских сайтов в целом не была успешной и долговременной. Идею виртуального представительства села земляки поначалу находили увлекательной, но постепенно такие сайты становились площадкой общения только для организаторов-энтузиастов, которые жаловались на пассивность основной части аудитории. На смену ностальгическиэмигрантским и вневременным сельским сайтам как раз и приходят WhatsApp- и Instagram-группы, мобильные и упрощенные, ориентированные не столько на мемориализацию локальной родины, сколько на повседневное общение и взаимопомощь внутри транслокального сообщества. Отчасти их прообразом были телефонные справочники односельчан, которые пытались выпускать некоторые сельские джамааты в 1990-е, учитывая там не только непосредственно жителей села, но и тех, кто выехал за его пределы, а также за пределы республики и даже 
страны. Например, такой справочник выпускался жителями села Чох и пользовался большим успехом до эпохи массового распространения мобильной связи - его можно было встретить на видном месте в домах чохцев-горожан еще в начале 2010-х годов.

Помимо общесельских групп, на базе социальных медиа организуются и специфические тематические сельские группы. Например, существуют свадебные группы, куда выкладываются фотографии и видеозаписи свадеб односельчан; группы автомобилистов района и другие. Сельчане могут объединяться в группы и по поводу какого-то конкретного события. Например, в одном из сел Цунтинского района создали группу «SOS», где земляков оповещают обо всех происшествиях и проблемах села (со временем группа стала общерайонной). Так, летом 2018 года там была размещена информация о пропаже мальчика. Предполагалось, что он утонул в горной реке, поэтому всех жители района приглашали на поисковую операцию по перегораживанию русла реки (для этого требовалась не одна сотня людей). Мобилизация людей через мессенджер произошла достаточно быстро, что свидетельствует о популярности группы. Подчас именно такие события и сподвигают сообщество к виртуальному объединению. Для жителей села Мокок Цунтинского района этим поводом стал разрушительный пожар в селе в 2016 году. Была создана группа помощи погорельцам, ставшая весьма активной, в нее вступили почти все выходцы из села, а через год группу переименовали в «Мокок» - и она стала просто общесельской.

Само существование социальных медиа может провоцировать людей на создание специфических объединений. Например, отсутствие социальной транспортной инфраструктуры в одном из весьма удаленных от основных трасс и порой труднодоступных горных районов побудило его жителей, активных пользователей социальных медиа, на создание собственной транспортной сети, в данном случае опять же на базе WhatsApp. По словам одного из моих информантов, почти все автомобилисты этого района (более 300 человек) объединились в специальную WhatsApp-группу и предоставляют услуги извоза землякам как за деньги, так и на безвозмездной основе: заглянув в эту группу, всегда можно найти попутчика, планирующего в ближайшее время выехать в райцентр, в столицу республики или обратно. Работа этого интернет-ресурса, по словам информанта, фактически вытеснила с рынка местных таксистов и решила проблему, связанную с труднодоступностью этого района.

Интересный вариант объединения сельчан, ставший актуальным после распространения социальных сетей, - религиозные (исламские) группы. Как правило, существуют строго мужские и строго женские группы.

Приведу в пример женскую группу из села Бежта. Основной целью членства в ней объявлено проведение совместных виртуальных зикров. Есть несколько виртуальных групп, в которых сельчанки (живущие в селе, в переселенческом селе на равнине, а также в столице и в городах за пределами Дагестана) совместно читают те или иные формы молитв.

Зейнаб создала две группы для чтения зикров пару лет назад, в ней состоит более сотни сельчанок, здесь читается зикр по тому или иному умершему - в 
одной группе за умершего 70000 раз читают молитву «Ла илаха иллаллах» (в течение одного дня), в другой - 4444 раза читают молитву «Салават ан-Нарият», исполняющую желания и избавляющую от бед (обычно читают в течение двух дней). Зейнаб признается, что раньше состояла в подобных общедагестанских группах, а потом, после смерти матери, решила создать нечто похожее для своих родственников.

Постепенно сельчане узнали об этой группе и стали просить Зейнаб «добавить» и их в нее. Группа ведется по-русски, поскольку те, кто вырос в городе, не очень уверено владеют аварским (официально бежтинцы причислены к аварцам) или бежтинским языком (несмотря на то, что есть словари этого языка, он считается бесписьменным). В итоге в одной из групп состоит около 120 человек, все они женщины - и жительницы Бежты, и жители Качалая (основное переселенческое село бежтинцев на равнине Дагестана), и Махачкалы, но все - бежтинцы. В другой группе - 40 женщин. Участница может предложить прочесть зикр за своего умершего родственника (по наставлению устаза можно читать и за живого человека), а остальные берут обязательства - кто сколько раз прочтет, а затем каждый отчитывается о выполненном задании в чате группы. Чтение длится один день, если за день не успевают - переносят на следующий или же участницы перекидывают запрос на чтение остатка молитв в другие WhatsApp-группы (как правило, это группы родственников). Раньше, до эпохи социальных медиа, этот зикр нужно было читать либо самостоятельно в течение многих дней, либо в составе группы в заранее установленном месте. Сейчас это стало практикой одного дня до эпохи социальных сетей сельчанину было сделать такое весьма трудно или даже невозможно. Помимо чтения зикров, участницы группы иногда обсуждают здесь разные вопросы, связанные с религией.

При этом мужчины Бежты, насколько мне известно, обычно не прибегают к интернет-зикрам, а собираются для его проведения каждый четверг в мечети. Женщины же в реальности собираются на чтение зикра реже и обычно у кого-то дома, многие не могут участвовать в таких собраниях, поскольку поглощены домашними делами. В этих условиях виртуальная практика в женских группах получила большое распространение, а социальные медиа здесь создают общий, вполне реальный опыт, который работает на объединение индивидов в сообщество (Komito 2011:26). Тот факт, что женский зикр перешел в виртуальную сферу, а мужской продолжает в основном пребывать в офлайне, может свидетельствовать и о гендерных предписаниях сообщества, которые в целом на сегодняшний день не поощряют активности женщин за пределами домашнего пространства. В этих условиях виртуальный зикр предоставляет возможность женщинам исполнять религиозный обряд и объединяться в религиозные сообщества, не выходя из дома.

Важным является также и то, как виртуальный зикр объединяет бежтинок, проживающих далеко друг от друга, фактически формируя единое религиозное сообщество.

Следует отметить, что религиозные дискуссии и практики в республике сейчас часто проходят в сети: чрезвычайно популярны интернет-проповедники суфистского (одобряемого официальным Духовным управлением мусульман России 
(ДУМ)), салафитского и других направлений. Даже сам ДУМ Дагестана, по сообщению информанта, который является имамом мечети в одном из селений, призывает имамов активно работать с прихожанами именно в сети.

\section{КОНСОЛИДАЦИЯ ТРАНСЛОКАЛЬНОЙ СЕМЬИ И РОДСТВЕННЫХ ГРУПП}

Семья и семейно-родовое объединение тухум также консолидируется и имеет возможность решать семейные задачи в условиях транслокальности. Действительно, транслокальность как жизненная стратегия, в первую очередь затрагивает такой социальный институт, как семья. Классической схемой становится отъезд части членов семьи в миграцию, тогда как другие остаются в месте отправления, при этом пытаясь воспроизводить множественные семейные практики и формируя новые - специфические транслокальные (Glick Schiller and Levitt 2004; на постсоветском материале см., например: Борисова 2017; Толстокорова 2012). Транслокальная семья в условиях территориальной разобщенности остро нуждается в поддержании единства. Неудивительно, что именно члены трансмигрантских семей, разделенные расстояниями, активно потребляют разного рода социальные медиа. В этих условиях социальные медиа успешно влияют на укрепление сильных связей - в частности, семейно-родственных коллективов.

В случае с дагестанской трансмиграцией важным становится поддержание связей и чувства единства не только с малой семьей или членами одного домохозяйства, но и с более широким семейно-родственным объединением - тухумом.

Исходя из данных наблюдений и интервью, можно сделать вывод, что одна из самых популярных и типичных WhatsApp-групп для республики - именно тухумная группа, которую условно можно назвать «родня». Часто эти группы так и именуются в телефонах пользователей («родня», «родные»- и по-русски, и на их родных языках), нередко встречались и названия самих тухумов. Например, в группе родственников Исмаила из Цунтинского района состоит 42 родственника по линии отца, группа называется «Халилал илласагатли» (родственники тухума Халиллал). На заставке группы старинная фотография покойных дедушки и бабушки отца моего информанта. Сам Исмаил почти десять лет не жил в родном горном селении: сначала он учился в Махачкале, потом продолжил обучение и проходил практику в одном из крупных городов страны, но уже год как вернулся в селение. Родственники Исмаила живут как в своем родном селении, так и в переселенческом селе на равнине Дагестана, а также в нескольких городах республики, в Москве, Санкт-Петербурге, других российских городах (кто-то из них живет там постоянно, кто-то в более-менее продолжительной трудовой миграции).

В некоторых группах состоят родственники обоих полов, другие объединяют только женщин или только мужчин. У мамы Исмаила, постоянно живущей в селении, есть своя группа с названием «Родня», куда входят все женщины тухума Раджабилал (15 человек) - вне зависимости от места постоянного проживания.

Родственные группы в социальных сетях могут решить не только общую проблему разобщенности родственников в условиях транслокальной жизни многих из них, но и весьма специфические, «тухумные» задачи. 


\section{ОРГАНИЗАЦИЯ ЗНАЧИМЫХ РИТУАЛОВ}

Приведу один из примеров того, какую роль для сообщества играют виртуальные социальные сети. Даже в условиях активной миграции как внутри Дагестана, так и за его пределы, ориентация на брак с односельчанами/выходцами из одного селения (а порой и родственниками) все еще остается приоритетом для большинства дагестанских сельчан или недавних мигрантов из сел в города Дагестана. В этом случае для поиска брачного партнера и организации мероприятий семья мигрантов, живущих за пределами республики, может воспользоваться помощью оставшихся в селе родственников - и здесь также все большую роль играют социальные медиа и возможности, предоставляемые ими (особенно пересылка фото- и видеоматериалов).

Вот, и он потом сказал: «Найдите девочку такую, всю порядочную, я женюсь». И Кавсарат родная тетя, наша двоюродная, она предложила: «Чего вы там, тут ищите», - говорит, - «на Кавсарат посмотрите, ей 17 исполнилось». Я говорю: «0на же это, родственница». Она говорит: «Чего», - говорит, - «она вам по крови родственница, что ли?». Такая, посмотрите на нее, говорит, чего вы на нее не смотрите? Ну так посмотрели видео [снятое] на свадьбе, я ее тоже не помнила. Она же... я уже много лет здесь [в Новом Уренгое] была. Ну, так в Дагестан когда приедешь, ну придешь ты к ним в гости, не каждое же время же она будет там сидеть меня ждать. И посмотрели - хорошенькая девочка. Показали брату, сказал: «Ну нормально». И все (ПМА 2019, Эльмира, 44 года, Новый Уренгой, Ямало-Ненецкий автономный округ).

Примечателен следующий пример. Одному моему информанту, чья семья уже долгое время живет в одном из городов Западной Сибири, невесту подобрали родственницы матери, живущие в его родном селе, причем они взяли на себя все хлопоты по организации сватовства и вручению необходимых подарков стороне невесты. Важно отметить, что все переговоры шли через Skype и WhatsApp, жениху и родителям посылали подробные фото- и видеоотчеты, переводы денег на траты, связанные со сватовством, также были сделаны при помощи интернета. Поэтому жених с семьей мог позволить себе приехать в Дагестан непосредственно перед свадьбой, через неделю он уже вернулся на Север с супругой. В итоге эта свадьба была организована и вообще состоялась (учитывая тот факт, что выбор невесты также шел посредством переговоров в социальных сетях) в значительной мере при помощи интернет-коммуникаций разного типа: общения, пересылки фото- и видеоматериалов, денежных транзакций.

Судя по всему многочисленные фото и видео со свадеб, передаваемые через родственников, играют ту же роль, что популярная до недавнего времени практика пересмотра видеокассет, а позже DVD, со съемками свадеб. Помимо приятных воспоминаний о важном событии в кругу семьи и мемориализации статуса самого события ${ }^{7}$, стоит учитывать и еще одну функцию просмотра свадебных фотографий. Изящнее всего ее выражает популярная в Дагестане поговорка «свадьба де-

7 Очевидно, что пышные свадьбы в регионе - значимый механизм поддержания социального престижа, семейной реципроктности и актуализации социальных связей. 
лает свадьбу». Потенциальные женихи и невесты нередко высматриваются желающими вступить в брак (а чаще - их бдительными родственниками) именно на свадьбах. Мигранты, проводящие много времени вдали от селения или республики, не всегда имеют возможность приехать на свадьбы близкой родни, а уж о том чтобы посещать свадьбы массово - во время их «сезона», - речь вообще не идет. Таким образом, можно быть недостаточно сведущим (если речь идет о женихе) или сведущей (есть речь о близких родственницах жениха) в новостях «брачного рынка». На помощь приходят DVD или уже упоминавшиеся выше специальные свадебные WhatsApp-группы. Одна моя информантка, живущая в селе, упомянула, говоря о выборе невесты для долго находящегося в миграции в западносибирском городе сына, что для этих целей она взяла несколько последних свадебных DVD у своих родственников, чтобы - в буквальном смысле - «отсмотреть невест». Судя по тому, что свадебные фото и видео - одни из самых востребованных в родственных группах социальных сетей, а также по тому, что информанты упоминали о существовании свадебных групп того или иного селения, WhatsApp также является ресурсом для поиска брачного партнера, особенно и прежде всего - в условиях миграции.

Очевидно, что при физической разобщенности ориентированного на эндогамию сельского сообщества возможность использования социальных медиа для поиска брачных партнеров и организации свадеб на расстоянии позволяет поддерживать актуальность традиции эндогамии. Вероятно, в условиях подобной масштабной и долговременной миграции она могла бы быть значительно редуцирована, если бы не существовало подобных виртуальных практик.

\section{ЭКОНОМИЧЕСКИЕ ФУНКЦИИ СОЦИАЛЬНЫХ МЕДИА ДЛЯ ТРАНСЛОКАЛЬНОГО СООБЩЕСТВА}

Сельские группы служат и площадкой для продвижения бизнеса, главным образом - для торговли. В сети продают машины, одежду, косметику и т. д. Наблюдая за группами в «ВКонтакте» и Instagram, я замечаю, что многие бизнесы в миграции связаны именно с торговлей этническими специалитетами и продуктами питания с малой родины, исламскими товарами; кроме того, есть много предложений и запросов на работу с земляками, аренду жилья. Торговля по сетям социальных медиа решает для трансмигранта сразу несколько задач: он, используя уже эти имеющиеся социальные сети, может не только решить проблему поиска работы в принимающем обществе, но и снизить связанные с этим риски, в том числе и дискриминационного характера (кавказофобия и вызванные ею феномены наподобие карьерного «стеклянного потолка» и дискриминации - то, о чем упоминают многие информанты). Здесь социальные медиа играют значительную роль, продуктивно актуализируя слабые связи земляков-дагестанцев при решении насущных проблем трансмигрантов.

\section{БЕЗОПАСНОСТЬ МИГРАНТОВ}

Через закрытые группы WhatsApp могут решаться и вопросы безопасности мигранта в принимающем сообществе. Один мой информант, работающий в Сургуте, утверждал, что в случае опасности через WhatsApp-группы за десять минут может 
собрать несколько десятков, а за полчаса - и несколько сотен земляков, живущих в этом регионе и готовых оказать силовую поддержку. Говорил он об этом мобилизационном ресурсе в контексте беседы о безопасности мигранта-дагестанца в западносибирском городе. Путем такого привлечения земляков (здесь в основном молодых мужчин) открывались и закрывались многие конфликтные ситуации. Не всегда сбор людей означал насилие, не всегда этот сбор в реальности происходил, но сама возможность (о которой нередко были оповещены и оппоненты), а главное - скорость исполнения этого - могла быть аргументом в споре. Примечательно, что именно такая форма «вацап-мобилизации» упоминалась как источник опасности моими собеседниками-недагестанцами ${ }^{8}$, которые были в целом негативно настроены по отношению к мигрантам из Дагестана. Вероятно, такая опасность дагестанских мигрантов воспринимается как стереотипная для принимающего сообщества «российского» города.

Несмотря на большое значение социальных медиа для функционирования транслокального сообщества, очевидно, что есть ситуации, когда накладываются ограничения на их использование - в случае если оно считается неприличным или неуместным. Так, по словам информантов, отдавать долг или направлять деньги на помощь селению, находясь в миграции, посредством интернет-технологий считается нормальным, однако передавать деньги в качестве поддержки при соболезнованиях или в качестве подарка на свадьбу таким образом не принято - это неприлично. Мигранты могут передать деньги с кем-то из земляков, выезжающих домой, или лично, после возвращения в село - это воспринимается как акт уважения: «Если бы я была матерью и моему сыну на свадьбу деньги на карточку [кинули], это было бы некрасиво» (ПМА 2018, Карина, 27 лет, Сургутский район, ХантыМансийский автономный округ).

\section{СОЦИАЛЬНЫЕ МЕДИА, СОЦИАЛЬНЫЙ КАПИТАЛ И РЕПУТАЦИЯ}

Из приведенных выше примеров следует, что социальные медиа предоставляют мигранту определенный ресурс, который он может задействовать в разных ситуациях, апеллируя к социальным институтам: родственному объединению, локальному сообществу, группе мужчин-земляков или верующих и т. д. Участие в закрытых земляческих или родственных группах социальных медиа может дать возможность для формирования и реализации социального капитала мигранта, поскольку эти группы как раз предоставляют герметичность социальных отношений, которую Джеймс Коулман считал необходимым условием формирования социального капитала (Coleman 1988; Portes 1998).

Понятие социальный капитал часто применяется в контексте миграции. Некоторые исследователи осмысляют отношения между социальными сетями и миграцией именно с учетом того, способствует ли капитал формированию социаль-

8 Некоторые мои случайные собеседники, узнав о цели моего исследования, порой спешили поделиться своим мнением о дагестанской миграции. 
ных связей и социального капитала и каким образом это происходит (Castles and Miller 2009; Dekker and Engbersen 2014; Komito 2011; Komito and Bates 2009).

Социальные медиа, в частности, могут стать хорошим ресурсом для мигранта, причем как перекидывающим мигранту «мост» в новый мир принимающего общества (bridging social capital), так и обеспечивающим ему связь прежде всего с все еще релевантным для него отправляющим обществом (bonding social capital). Разные мигрантские группы реализуют разные варианты использования социальных сетей в интернете: например, в исследованиях Ли Комито показано, что социальные медиа чаще используются для связи с отправляющим, нежели с принимающим, миром, с теми, кого человек уже знает в реальной жизни (Komito 2011), тогда как в работе Ксиньян Ванг молодые мигранты, приехавшие с целью трудоустройства из китайской деревни в китайский индустриальный центр, больше использовали социальные медиа не для связи с оставленным сообществом, а для нового мира, моделируя таким образом проекцию идеального современного образа жизни, о котором мечтали (Wang 2016:2). Безусловно, это связано, помимо различных значимых характеристик самих сообществ, и со степенью распространенности интернет-коммуникаций в отправляющем обществе. Так, например, почти тотальная интернетизация дагестанских селений и доступность мобильного интернета и телефонов позволяет находящимся в миграции общаться не только с оставшейся в Дагестане молодежью, но и со старшим поколением, которое активно осваивает социальные сети. Например, о практике виртуальных зикров в селении я узнала почти случайно, увидев смартфон в руках у пожилой сельчанки и поинтересовавшись, что она с ним делает в данный момент. Активно пользовались социальными медиа и другими интернет-коммуникациями и другие мои информанты старшего поколения.

Тем не менее, поскольку социальный капитал обладает амбивалентностью, то есть может быть как позитивным, так и негативным (Portes and Sensenbrenner 1993), социальные медиа могут и сформировать позитивный образ мигранта в сообществе, и нанести ему определенный репутационный урон ${ }^{9}$.

Так, вступление в группу, где читают зикр, может характеризовать человека как набожного в глазах своего локального сообщества, а свадебная группа помогает упрочить статус, говорит о достатке и влиятельности семьи, которая провела свадебное торжество. Однако сокращение социальной дистанции между местами отправления и принятия мигрантов и более интенсивное общение в рамках сельских и родственных сетей лишает мигранта некоторой доли «невидимости» и оторванности от земляков, которой прежде характеризовалась миграция. Например, мне приходилось встречать в группе «ВКонтакте», объединяющей живущих в Санкт-Петербурге мусульман, гневные реплики блюстителей нравственности в адрес того или иного выходца из Дагестана (в попадавшихся мне примерах это были женщины) с призывом донести о ее/его недостойном поведении (в том чи-

9 Транснациональный социальный капитал не только обеспечивает доступ к ресурсам, но, одновременно, и ограничивает личную свободу. Например, в случае трудовой миграции - когда через социальные медиа оставшиеся в селе родственники могут корректировать работу человека в миграции (см. историю про узбекских мигрантов в Москве: Уринбоев 2020 ). 
сле и в сети) родне в Дагестане. Таким образом, мигрант остается в значительной степени зависимым от принятых в отправляющем сообществе норм и практик, поскольку зачастую находится на виду у этого общества - в том числе и через посредничество социальных медиа. Впрочем, можно говорить и о том, что подобная «видимость» мигранта для отправляющего сообщества в определенной степени влияет на его вовлеченность в жизнь сообщества принимающего и ограничивает степень его адаптации к принятым там нормам социальной жизни и публичного поведения.

Негативный социальный капитал, который можно «заработать» в земляческих группах, может создать трансмигранту ощутимые проблемы, прежде всего по возвращении в отправляющее сообщество. Так, в рамках социальных медиа создаются группы, чьей миссией их участники фактически объявляют контроль за моральным обликом земляков. Это одно из проявлений общественного контроля нравственности в республике (и шире - нравственности выходцев из нее), получившего распространение в условиях процессов реисламизации региона и развития идей традиционализма.

Прежде всего деятельность подобных интернет-сообществ угрожает безопасности молодых женщин и представителей сексуальных меньшинств. Яркий пример - группа «Нетипичная Махачкала» в социальной сети «ВКонтакте». Эта группа позиционировалась как собрание шуток и необычных происшествий в дагестанской столице. Однако в дальнейшем здесь начали размещать фото и видео людей, которые, по мнению авторов публикации, повели себя недостойно, нарушили правила приличия дагестанского общества и религиозного благочестия. Подавляющее большинство публикаций было посвящено поведению или облику молодых девушек. Участники группы часто выкладывали в группу съемки незнакомых и знакомых девушек, сделанные ими, как правило, в публичных местах. Кроме того, молодые люди, которые встречались с девушками, могли позже разместить их фото и видео интимного характера в этой группе, практиковались также и взломы телефонов и страниц девушек в социальных сетях. Попадавшие в группу материалы часто снабжались персональной информацией жертв, после чего нередко следовала травля, угрозы насилия, сексуальные домогательства и т. п.

Популярность и влиятельность «Нетипичной Махачкалы» были так велики, что одна из местных телекомпаний даже сняла небольшой фильм, где осуждались эта и ей подобные группы. В фильме выступали журналисты, правозащитники, имамы, местные знаменитости. Таковые группы позиционируют себя как общедагестанские, их деятельность не направлена именно на мигрантов. Тем не менее эти сообщества безусловно известны находящимся в режиме трансмиграции дагестанцам, их специфика и влияние берется последними во внимание. Например, моя информантка Карина, почти всю жизнь прожившая в Сургутском районе (ее семья живет транслокальной жизнью уже почти 30 лет), рассказывала, что по приезде в Дагестан ее внешний вид (в частности, одежда) неоднократно подвергался критике со стороны незнакомых ей людей на улицах родного села и дагестанских городов. Помимо угрозы насилия, она опасалась, что ее снимут на камеру телефона и отправят это видео в группу, подобную «Нетипичной Махачкале». После это- 
го ее репутация в глазах земляков может пострадать (особенно учитывая, что на тот момент она еще была не замужем).

Интересно, что в локальных сельских и тем более родственных группах тема публичного подрыва репутации, по словам моих информантов, нетипична: здесь персонифицирована не только жертва, но и «обвинитель», что может спровоцировать насилие уже по отношению к нему и ответное обвинение в распутстве уже его родственниц. В узких родственных группах это и вовсе теряет смысл, а если обсуждение и происходит, то скрыто и в устной форме.

В условиях угроз публичного осуждения и последующего за ним насилия в Дагестане активно развиваются анонимные социальные сети, где люди, боясь огласки и осуждения со стороны земляков и расправы как со стороны незнакомцев, так и близких родственников, обсуждают различные проблемы. В соцсетях «ВКонтакте» и в Instagram, в частности, есть группы, где женщины (преимущественно) делятся своими историями семейной и сексуальной жизни, просят совета, ищут единомышленников. Важная особенность - администратор группы по желанию авторов гарантирует им анонимность, но все равно большинство постов заканчивается словами «Админ, прошу анонимно!». Исходя из контента, можно с уверенностью сказать, что анонимность здесь - не только защита от репутационных потерь, но и от физической расправы со стороны знакомых и незнакомых соотечественников.

Социальные медиа делают мигранта не только видимым для своего сообщества, но и «зрячим» по отношению к этому сообществу. Это тоже может сказаться на социальных взаимодействиях в условиях транслокальности. В качестве примера приведу случай в семье моего информанта Магомеда. Проживая более десяти лет в миграции в Сургуте, он решил жениться и засватал девушку из родного селения (в котором она и жила). Однако спустя некоторое время свадьба расстроилась, поскольку жених после сватовства поставил девушке условие: не «сидеть в соцсетях» по вечерам (классическая форма контроля за женской нравственностью, очень популярная на Кавказе). Позже, застав ее после этого запрета в популярной соцсети в непозволительное для нее вечернее время (то есть просто заметив, что она была онлайн), он расторг помолвку, мотивировав это тем, что если она до свадьбы не слушается его, то не будет слушаться и после свадьбы. Нравственность и благообразность девушки, таким образом, была отслежена лично женихом через использование социальной сети, при этом он находился на расстоянии нескольких тысяч километров от неудачливой невесты.

\section{ЗАКЛЮЧЕНИЕ}

Социальные исследования новых интернет-коммуникаций применительно к теме миграции показали их специфическое влияние на миграционные практики. Например, использование новых интернет-медиа помогает мигрантам поддерживать прочные связи с семьей и друзьями; создает новую инфраструктуру, состоящую из скрытых связей; предоставляет возможность контактов со слабыми связями, которые имеют отношение к организации процесса миграции и расселения; дает 
много неофициальных инсайдерских знаний о миграции (Dekker and Engbersen 2014, цит. по: Plaza and Bellow 2014).

В задачи этой статьи входила не только верификация этих выводов на материале внутрироссийской миграции из Дагестана, обладающей признаками транслокальности, но и выявление некоторой специфичности дагестанского случая в общем ряду транслокальных мигрантских кейсов.

Рассмотрены варианты и специфика функционирования социальных медиа в контексте формирования и существования транслокальных сообществ Дагестана, сформированных чаще всего на основе сельской локальности. Мои материалы подтверждают большое значение распространения повседневных интернет-контактов, прежде всего через социальные медиа, между мигрантами и членами отправляющего сообщества для сохранения режима именно транслокальной миграции. Мобильные социальные сети становятся важным механизмом поддержания социальных связей в дагестанском транслокальном сообществе, дают возможность действовать быстро и слаженно. Через популярные социальные медиа происходит также формирование единого информационного пространства внутри транслокального сельского сообщества, а через это и консолидация транслокального сельского сообщества в целом. Расширяется информационное поле транслокального общества - все его члены через такие группы мгновенно узнают о важных для сообщества событиях. Трансмигранты не теряют ресурса вовлеченности в сельскую жизнь в формате «здесь и сейчас». В этом случае социальные сети более эффективны и полезны для транслокального сообщества, чем их предшественники - сельские сайты, не позволившие объединить большие группы людей, при этом активность их пользователей была больше направлена на коммеморацию общей идентичности, чем на установление прочных и востребованных повседневных актов коммуникации.

В итоге, существуя в виртуальной реальности и соединяя расположенные на значительном удалении друг от друга локальности, сельские и тухумные группы в социальных сетях, тем не менее, консолидируют сообщество непосредственного взаимодействия и во многом позволяют этому сообществу оставаться таковым, несмотря на сотни и тысячи километров, которые разделяют его участников.

Трансмигранты активно используют социальные медиа в миграции для организации бизнеса, в том числе и транслокального (то есть построенного на мобильности между двумя локальностями - в случае с Дагестаном это прежде всего перевозка продуктов питания и торговля ими).

Социальные медиа могут предоставить новые варианты исполнения существующих религиозных обрядов, одномоментно соединяя разделенных километрами людей. При этом модифицируется даже сама форма исполнения обряда - например, длительность и массовость.

В условиях глобального мира и транслокальной специфики сообществ возникает вопрос о влиянии социальных медиа на репутацию члена сообщества, который несет немало рисков для некоторых категорий людей, в первую очередь - для молодых женщин. Благодаря социальным медиа трансмигранты, находящиеся за многие километры от Дагестана, становятся более видимы для отправляющего со- 
общества, чем до эпохи массового распространения интернет-коммуникаций, а также сами получают информацию о членах сообщества в формате реального времени и персонально, что также может модифицировать социальное взаимодействие в транслокальном коллективе.

\section{СПИСОК ЛИТЕРАТУРЫ}

Борисова, Елена. 2017. «Детская мобильность в контексте миграции из Таджикистана». Социологические исследования 8:73-80. doi:10.7868/S0132162517080086.

Бредникова, Ольга. В печати. «Мобильная связь мобильного субъекта (опыт социологического прочтения мобильного телефона)». В Сети города. Люди. Технологии. Власть, под ред. Екатерины Лапиной-Кратасюк, Оксаны Запорожец и Андрея Возьянова. М.: Новое литературное обозрение.

Глянц, Анна. 2018. «Принадлежность к мусульманской общности в Дагестане: анализ институтов и практик». Антропологический форум 36:154-182. doi:10.31250/1815-8870-2018-14-36-154-182.

Капустина, Екатерина. 2012. «Сельские землячества как элемент социальной культуры современной Махачкалы». С. 379-383 в Северокавказский город в региональном историческом процессе. Материалы международной научной конференции (Каспийск. 18-19 сентября 2012 года), под ред. Эльмиры Далгат и Амины Халиловой. Махачкала: Типография Алеф.

Капустина, Екатерина. 2017. «Между Севером и землей: дорога из Западной Сибири в Дагестан как элемент социального пространства транслокального мигранта». Социологические исследования 5:26-34.

Карпов, Юрий и Екатерина Капустина. 2011. Горцы после гор. Миграционные процессы в Дагестане в XX - начале XXI веков: история, социокультурные и этнополитические результаты. СПб.: Петербургское востоковедение.

Толстокорова, Алиса. 2012. «"Мама моет раму в Риме”: Гендерные аспекты транснационального родительства в Украине». Журнал исследований социальной политики 3:396-408.

Уринбоев, Рустамжон. 2020. «Создание "узбекской махалля" посредством смартфонов и социальных медиа: повседневная транснациональная жизнь узбекских мигрантов в России». С. 442-481 в «Жить в двух мирах»: переосмысляя транснационализм и транслокальность, под ред. Сергея Абашина и Ольги Бредниковой. СПб.: Новое литературное обозрение.

Ярлыкапов, Ахмет. 2014. «Ислам и конфликт на Кавказе». С. 183-215 в Большой Кавказ двадцать лет спустя. Ресурсы и стратегии политики идентичности, под ред. Гасана Гусейнова. М.: Новое литературное обозрение.

Asal, Houda. 2012. “Community Sector Dynamics and the Lebanese Diaspora: Internal Fragmentation and Transnationalism on the Web." Social Science Information 51(4):502-520. doi:10.1177/0539018412456768.

Brekke, Marianne. 2008. “Young Refugees in a Network Society." Pp. 103-114 in Mobility and Place: Enacting Northern European Peripheries, ed. by Jørgen Ole Bærenholdt and Brynhild Granås. Aldershot, UK: Ashgate.

Cairncross, Frances. 1997. The Death of Distance: How the Communications Revolution Will Change Our Lives. Boston: Harvard Business School Press.

Castles, Stephen, and Mark J. Miller. 2009. The Age of Migration: International Population Movements in the Modern World. 4th ed. New York: Guilford Press.

Cohen, Robin. 1997. Global Diasporas: An Introduction. Seattle: University of Washington Press.

Coleman, James S. 1988. "Social Capital in the Creation of Human Capital." American Journal of Sociology 94(Supplement):S95-S120.

Dekker, Rianne, and Godfried Engbersen. 2014. “How Social Media Transform Migrant Networks and Facilitate Migration." Global Networks 14(4):401-418.

Faist, Thomas. 2010. "Diaspora and Transnationalism: What Kind of Dance Partners?" Pp. 9-34 in Diaspora and Transnationalism: Concepts, Theories and Methods, ed. by Rainer Bauböck and Thomas Faist. Amsterdam: Amsterdam University Press. 
Glick Schiller, Nina, Linda Basch, and Cristina Blanc-Szanton. 1992. “Towards a Definition of Transnationalism: Introductory Remarks and Research Questions." Pp. ix-xiv in Towards a Transnational Perspective on Migration: Race, Class, Ethnicity, and Nationalism Reconsidered, ed. by Nina Glick Schiller, Linda Basch, and Cristina Blanc-Szanton. New York: New York Academy of Sciences.

Glick Schiller, Nina, and Peggy Levitt. 2004. “Conceptualizing Simultaneity: A Transnational Social Field Perspective on Society." International Migration Review 38(3):1002-1039.

Goldring, Luis. 1999. "Power and Status in Transnational Social Spaces." Pp. 162-186 in Migration and Transnational Social Spaces, ed. by Ludger Pries. Aldershot, UK: Ashgate.

Greiner, Clemens. 2010. “Patterns of Translocality: Migration, Livelihoods and Identity in Northwest Namibia." Sociologus 60(2):131-161.

Greiner, Clemens, and Patric Sakdapolrak. 2013. “Translocality: Concepts, Applications and Emerging Research Perspectives." Geography Compass 7(5):373-384. doi:10.1111/gec3.12048.

Horst, Heather A. 2006. "The Blessings and Burdens of Communication: Cell Phones in Jamaican Transnational Social Fields." Global Networks 6(2):143-159.

Ignacio, Emily N. 2005. Building Diaspora: Filipino Cultural Community Formation on the Internet. New Brunswick, NJ: Rutgers University Press.

Kapustina, Ekaterina. 2019. "The Boundaries of the Djamaat: The Particular Features of Dangestan's Translocal Communities in the Context of Migration Flows within the Russian Federation." Journal of Social Policy Studies 17(1):103-118. doi:10.17323/727-0634-2019-17-1 $-103-118$.

Komito, Lee. 2011. "Social Media and Migration: Virtual Community 2.0." Journal of the American Society for Information Science and Technology 62(6):1075-1086. doi:10.1002/asi.21517.

Komito, Lee, and Jessica Bates. 2009. "Virtually Local: Social Media and Community among Polish Nationals in Dublin." ASLIB Proceedings 61(3):232-244.

Levitt, Peggy. 2001. The Transnational Villagers. Berkeley: University of California Press.

Madianou, Mirca, and Daniel Miller. 2012. Migration and New Media: Transnational Families and Polymedia. London: Routledge.

Miller, Daniel. 2011. Tales from Facebook. Cambridge: Polity Press.

Miller, Daniel, and Heather A. Horst. 2012. “The Digital and the Human: A Prospectus for Digital Anthropology." Pp. 3-38 in Digital Anthropology, ed. by Heather A. Horst and Daniel Miller. London: Bloomsbury Academic.

Peleikis, Anja. 2003. Lebanese in Motion: Gender and the Making of a Translocal Village. Bielefeld, Germany: Transcript Verlag.

Plaza, Dwaine, and Amy Below. 2014. "Social Media as a Tool for Transnational Caregiving within the Caribbean Diaspora." Social and Economic Studies 63(1):25-56.

Portes, Alejandro. 1998. "Social Capital: Its Origins and Applications in Modern Sociology." Annual Review for Sociology 24:1-24.

Portes, Alejandro, and Julia Sensenbrenner. 1993. “Embeddedness and Immigration: Notes on the Social Determinants of Economic Action." American Journal of Sociology 98(6):1320-1350.

Smith, Michael Peter, and Luis Eduardo Guarnizo. 1998. "The Locations of Transnationalism." Pp. 3-31 in Transnationalism from Below, ed. by Michael Peter Smith and Luis Eduardo Guarnizo. New Brunswick, NJ: Transaction Publishers.

Tölölyan, Khachig. 1996. "Rethinking Diaspora(s): Stateless Power in the Transnational Moment." Diaspora: A Journal of Transnational Studies 5(1):3-36.

Vertovec, Steven. 2004. “Cheap Calls: The Social Glue of Migrant Transnationalism." Global Networks $4(2): 219-224$.

Wang, Xinyuan. 2016. Social Media in Industrial China. London: UCL Press. 


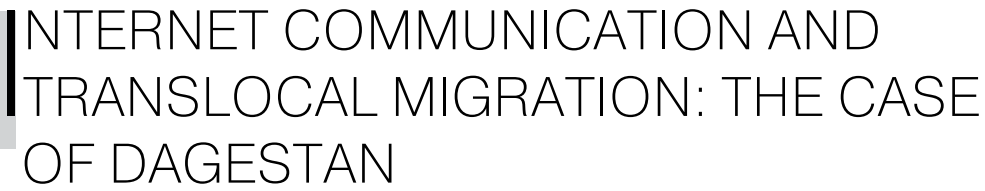

\section{Ekaterina Kapustina}

Ekaterina Kapustina, Peter the Great Museum of Anthropology and Ethnography, Russian Academy of Sciences; European University at St. Petersburg. Address for correspondence: MAE RAS, Universitetskaia nab., 3, Saint Petersburg, 199034, Russia.parlel@mail.ru.

This study, conducted within European University at St. Petersburg (2017-2018), was supported by the Russian Science Foundation grant No. 14-18-02149-7 "Transnational and Translocal Aspects of Migration in Modern Russia."

The article examines the mechanisms of functioning of internet communication and social networks in the translocal rural communities of Dagestan, a Russian Federation region in the North Caucasus, whose members have been participating in the labor migration to industrial Russian cities. Huge distances and various sociocultural and economic differences between the sending and the receiving societies pose a challenge to the unity of the rural community, djamaat. Rural identity is salient for migrants: they preserve the principle of rural endogamy, bury all the dead migrants in their village, spend money and time on the development of the village, and create public organizations of fellow villagers. The article focuses on the practice of using mobile social networksFacebook and its Russian counterparts-by transmigrants, their families, and fellow villagers. Social media provide everyday family communication and serve as a platform for performing important social rites such as finding a bride, matchmaking, remitting money for condolences, as well as transferring important information between migrants and those living in the village. Rural chats consolidate the community and formulate the idea of the unity and also become power and economic resources for migrants. At the same time, the villagers' chats are the places where the laws of reputation are at work, therefore they can also demonstrate positive or negative social capital and carry a danger for migrants, especially for women.

Keywords: Translocal Community; Migration; Digital Anthropology; Social Media; Social Networks of Migrants; Social Capital

\section{REFERENCES}

Asal, Houda. 2012. "Community Sector Dynamics and the Lebanese Diaspora: Internal Fragmentation and Transnationalism on the Web." Social Science Information 51(4):502-520. doi:10.1177/0539018412456768.

Borisova, Elena. 2017. “Detskaia mobil'nost' v kontekste migratsii iz Tadzhikistana." Sotsiologicheskie issledovaniia 8:73-80. doi:10.7868/S0132162517080086.

Brednikova, Olga. Forthcoming. "Mobil'naia sviaz' mobil'nogo sub"ekta (opyt sotsiologicheskogo prochteniia mobil'nogo telefona)." In Seti goroda: Liudi, Tekhnologii, Vlast', ed. by Ekaterina Lapina-Kratasyuk, Oksana Zaporozhets, and Andrey Vozyanov. Moscow: Novoe literaturnoe obozrenie. 
Brekke, Marianne. 2008. "Young Refugees in a Network Society." Pp. 103-114 in Mobility and Place: Enacting Northern European Peripheries, ed. by Jørgen Ole Bærenholdt and Brynhild Granås. Aldershot, UK: Ashgate.

Cairncross, Frances. 1997. The Death of Distance: How the Communications Revolution Will Change Our Lives. Boston: Harvard Business School Press.

Castles, Stephen, and Mark J. Miller. 2009. The Age of Migration: International Population Movements in the Modern World. 4th ed. New York: Guilford Press.

Cohen, Robin. 1997. Global Diasporas: An Introduction. Seattle: University of Washington Press.

Coleman, James S. 1988. "Social Capital in the Creation of Human Capital." American Journal of Sociology 94(Supplement):S95-S120.

Dekker, Rianne, and Godfried Engbersen. 2014. “How Social Media Transform Migrant Networks and Facilitate Migration." Global Networks 14(4):401-418.

Faist, Thomas. 2010. "Diaspora and Transnationalism: What Kind of Dance Partners?" Pp. 9-34 in Diaspora and Transnationalism: Concepts, Theories and Methods, ed. by Rainer Bauböck and Thomas Faist. Amsterdam: Amsterdam University Press.

Glick Schiller, Nina, Linda Basch, and Cristina Blanc-Szanton. 1992. “Towards a Definition of Transnationalism: Introductory Remarks and Research Questions." Pp. ix-xiv in Towards a Transnational Perspective on Migration: Race, Class, Ethnicity, and Nationalism Reconsidered, ed. by Nina Glick Schiller, Linda Basch, and Cristina Blanc-Szanton. New York: New York Academy of Sciences.

Glick Schiller, Nina, and Peggy Levitt. 2004. “Conceptualizing Simultaneity: A Transnational Social Field Perspective on Society." International Migration Review 38(3):1002-1039.

Glyants, Anna. 2018. "Prinadlezhnost' k musul'manskoi obshchnosti v Dagestane: Analiz institutov i praktik." Antropologicheskii forum 36:154-182. doi:10.31250/1815-8870-2018-14-36-154-182.

Goldring, Luis. 1999. "Power and Status in Transnational Social Spaces." Pp. 162-186 in Migration and Transnational Social Spaces, ed. by Ludger Pries. Aldershot, UK: Ashgate.

Greiner, Clemens. 2010. "Patterns of Translocality: Migration, Livelihoods and Identity in Northwest Namibia." Sociologus 60(2):131-161.

Greiner, Clemens, and Patric Sakdapolrak. 2013. "Translocality: Concepts, Applications and Emerging Research Perspectives." Geography Compass 7(5):373-384. doi:10.1111/gec3.12048.

Horst, Heather A. 2006. “The Blessings and Burdens of Communication: Cell Phones in Jamaican Transnational Social Fields." Global Networks 6(2):143-159.

Ignacio, Emily N. 2005. Building Diaspora: Filipino Cultural Community Formation on the Internet. New Brunswick, NJ: Rutgers University Press.

Kapustina, Ekaterina. 2012. “Sel'skie zemliachestva kak element sotsial'noi kul'tury sovremennoi Makhachkaly." Pp. 379-383 in Severokavkazskii gorod v regional'nom istoricheskom protsesse: Materialy mezhdunarodnoi nauchnoi konferentsii, ed. by Elmira Dalgat and Amina Khalilova. Makhachkala, Russia: Tipografiia Alef.

Kapustina, Ekaterina. 2017. “Mezhdu Severom i zemlei: Doroga iz Zapadnoi Sibiri v Dagestan kak element sotsial'nogo prostranstva translokal'nogo migranta." Sotsiologicheskie issledovaniia $5: 26-34$.

Kapustina, Ekaterina. 2019. "The Boundaries of the Djamaat: The Particular Features of Dangestan's Translocal Communities in the Context of Migration Flows within the Russian Federation." Journal of Social Policy Studies 17(1):103-118. doi:10.17323/727-0634-2019-17-1 -103-118.

Karpov, Yuri, and Ekaterina Kapustina. 2011. Gortsi posle gor: Migratsionnye protsessy v Dagestane $v$ XX - nachale XXI vekov, ikh sotsial'nye i etnokul'turnye posledstviia i perspektivy. Saint Petersburg, Russia: Peterburgskoe vostokovedenie.

Komito, Lee. 2011. "Social Media and Migration: Virtual Community 2.0." Journal of the American Society for Information Science and Technology 62(6):1075-1086. doi:10.1002/asi.21517.

Komito, Lee, and Jessica Bates. 2009. "Virtually Local: Social Media and Community among Polish Nationals in Dublin." ASLIB Proceedings 61(3):232-244. 
Levitt, Peggy. 2001. The Transnational Villagers. Berkeley: University of California Press.

Madianou, Mirca, and Daniel Miller. 2012. Migration and New Media: Transnational Families and Polymedia. London: Routledge.

Miller, Daniel. 2011. Tales from Facebook. Cambridge: Polity Press.

Miller, Daniel, and Heather A. Horst. 2012. “The Digital and the Human: A Prospectus for Digital Anthropology." Pp. 3-38 in Digital Anthropology, ed. by Heather A. Horst and Daniel Miller. London: Bloomsbury Academic.

Peleikis, Anja. 2003. Lebanese in Motion: Gender and the Making of a Translocal Village. Bielefeld, Germany: Transcript Verlag.

Plaza, Dwaine, and Amy Below. 2014. "Social Media as a Tool for Transnational Caregiving within the Caribbean Diaspora." Social and Economic Studies 63(1):25-56.

Portes, Alejandro. 1998. "Social Capital: Its Origins and Applications in Modern Sociology." Annual Review for Sociology 24:1-24.

Portes, Alejandro, and Julia Sensenbrenner. 1993. “Embeddedness and Immigration: Notes on the Social Determinants of Economic Action." American Journal of Sociology 98(6):1320-1350.

Smith, Michael Peter, and Luis Eduardo Guarnizo. 1998. "The Locations of Transnationalism." Pp. 3-31 in Transnationalism from Below, ed. by Michael Peter Smith and Luis Eduardo Guarnizo. New Brunswick, NJ: Transaction Publishers.

Tölölyan, Khachig. 1996. "Rethinking Diaspora(s): Stateless Power in the Transnational Moment." Diaspora: A Journal of Transnational Studies 5(1):3-36.

Tolstokorova, Alisa 2012. “'Mama moet ramu v Rime': Gendernye aspekty transnatsional'nogo roditel'stva v Ukraine." Zhurnal issledovanii sotsial'noi politiki 3:396-408.

Urinboev, Rustamjon. 2020. “Sozdanie 'uzbekskoi makhallia' posredstvom smartfonov i sotsial'nykh media: Povsednevnaia transnatsional'naia zhizn' uzbekskikh migrantov v Rossii." Pp. 442481 in "Zhit'v dvukh mirakh": Pereosmysliaia transnatsionalizm i translokal'nost', ed. by Sergey Abashin and Olga Brednikova. Saint Petersburg, Russia: Novoe literaturnoe obozrenie.

Vertovec, Steven. 2004. "Cheap Calls: The Social Glue of Migrant Transnationalism." Global Networks 4(2):219-224.

Wang, Xinyuan. 2016. Social Media in Industrial China. London: UCL Press.

Yarlykapov, Akhmet. 2014. “Islam i konflikt na Kavkaze." Pp. 183-215 in Bol'shoi Kavkaz dvadtsat' let spustia: Resursy i strategii politiki identichnosti, ed. by Gasan Gusejnov. Moscow: Novoe literaturnoe obozrenie. 